\title{
イシダイ仔稚魚の成長に伴ら走光行動の変化
}

\author{
林 多恵子, 山川 紘, 松生 洽
}

(1991 年9月 26 日受付)

\section{Change in Phototactic Response with Growth of Striped Beakperch Larvae and Juveniles*1}

Taeko Hayashi, *2 Hiroshi Yamakawa, ${ }^{* 2}$ and Kanau Matsuike*2

The change in phototactic response of the striped beakperch Oplegnathus fasciatus and the preferred illuminance level were investigated. Furthermore, the occupation limit from brightness into darkness was also examined.

Larvae one day after hatching, with a total body length of $2.1 \mathrm{~mm}$, floated near the sea surface, but eyed larvae two days after hatching, with a length of $2.4 \mathrm{~mm}$, migrated to the brighter water area when they were in an illuminance of less than 2,500lx. Larvae at this stage already had a noticeable phototactic response. Juveniles 25 days after hatching, with a length of 10 to $14 \mathrm{~mm}$, and 45 days after hatching, with a length of 18 to $22 \mathrm{~mm}$, gathered in the brighter water area during the low illuminance level from 90 to $750 \mathrm{~lx}$, while at an illuminance of more than $2,800 \mathrm{~lx}$ their behaviour was distracted. In this stage of juveniles, an illuminance level of 750 to $1400 \mathrm{~lx}$ was favored. The occupation of juveniles from brighteness into darkness was limited by the horizontal gradient of illuminance, and the value of gradient that they could not enter was anything over $3 \% / \mathrm{cm}$.

イシダイ striped beakperch Oplegnathus fasciatus は全長 $2 \mathrm{~mm}$ 前啳の仔魚として艀化し, 約 20 日で全長 $8 \mathrm{~mm}$ から $9 \mathrm{~mm}$ に成長し，この段階で流れ藻に付く。 その後䄪 10 日で全長約 $10 \mathrm{~mm}$ に成長した頃，仔魚は稚 魚に移行する。稚魚は約 1 力月間，流れ藻に付いて生活 し、全長 $50 \mathrm{~mm}$ から $60 \mathrm{~mm}$ 程度に達した後には，流れ 藻から離九，沿岸岩礁域に定住する。的このように初期 のイシダイは成長段階により生息環境を大きく変える。

これらのことから, 魚の光に対する反応行動は成長に 伴い变化するもの上考光られるが，保稚魚の光に対主る 行動反応の変化に関しては，わずが矢野・小川”の報

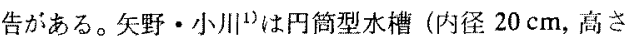
$130 \mathrm{~cm}$ ) スプルー・ブラックインタで染色した海水（照 度の消散倸数 $3.4 \mathrm{~m}^{-1}$ ) を入れ，海面上の照度を 130 $22001 x$ の間て变化させ，マダイ Pagrus major の鈆淔分 布を成長别に調べた。好適照度恃全長 $5 \sim 7 \mathrm{~mm}$ の仔魚 では 1600 2200lx であり，13〜15 mm の稚魚でけ 200 Ixであると能告した。

本研究では，棲息罢境が異なるイシダイの估期から 稚魚期にかけての走光行動の変化, 好適照度扣上び稚魚
期に括ける明暗境界域に対する行動反心を調べた。

\section{材料および方法}

イシダイ仔魚は 1990 年 7 月, 愛援県栽培漁策センタ 一に执いて睬化し (全長 $2.1 \mathrm{~mm}$ ), 翌日千葉罢館山市の 東㲾水痤大学坂田実験場に運搬した。実験室内に直径 $680 \mathrm{~mm}$ の透明なポりカーボネートタンタを設琶し深さ $40 \mathrm{~cm}$ まで㴽過海水を入九，その中に仔魚約 2000 尾を 取容した。水槽内の㴗济中央の 1 点で弱いエアレーショ

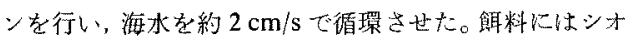
ミズッボワムシを用いた。シオミズッボワムシは海库ク

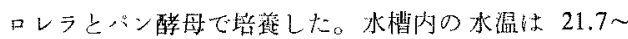
$26.0^{\circ} \mathrm{C}$ であった。

穛焦の採集は, 千葉紧房総半島の洲の埼沖合水域にお いて 1990 年 5 月ふら 7 月の間, 計 9 回行った。採捕 した全長 9 50 mm の稚焦 90 尾を空内噆育水槽（值径 $1000 \mathrm{~mm}$ 円型 FRP 水粕) に取容し、アルテミア纤生上 焦附ミンチで飼㕕した。

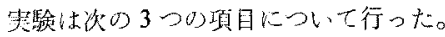

仔魚の走光行動 摪過酒水 (光束消散係数 $0.1 \mathrm{~m}^{-1}$ ) を

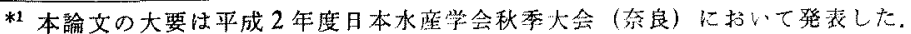

*2 東京水痖大学 (Tokyo University of Fisheries, Konan, Minato, Tokyo 108, Japan).

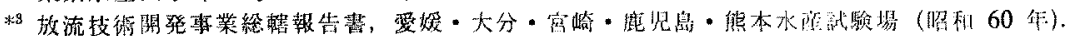



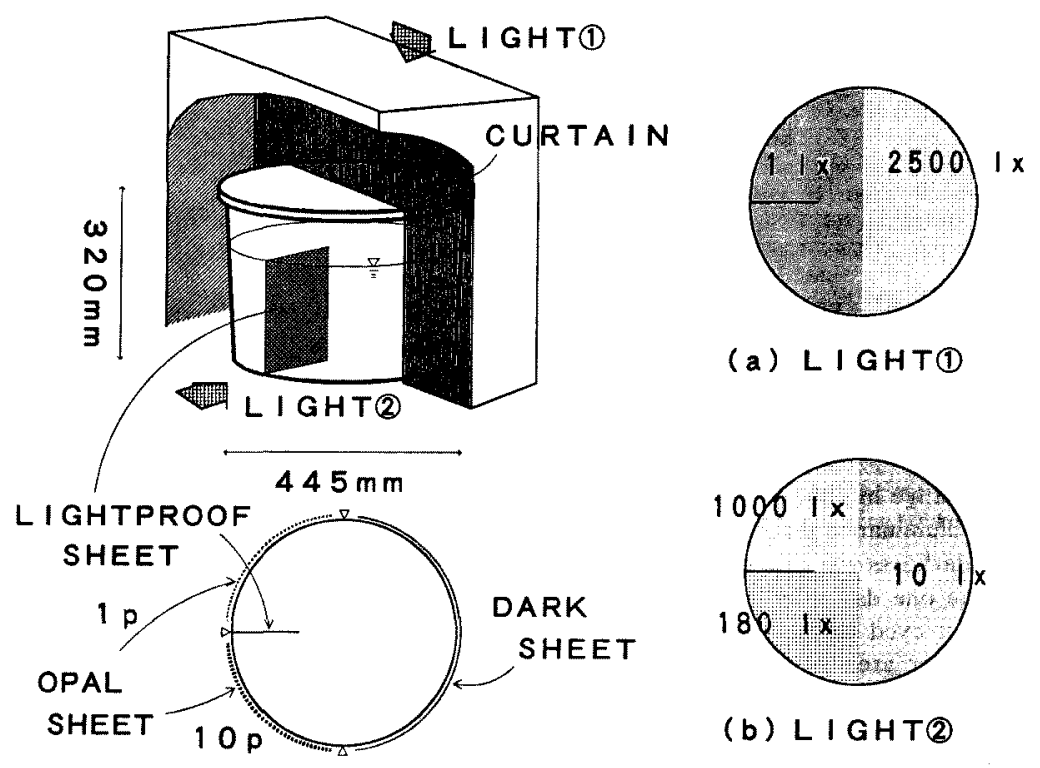

(a) L I GHT(1)

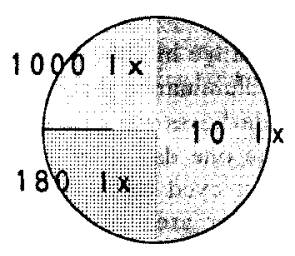

(b) L I GHT(2)

Fig. 1. Sketch of experimental tank and distribution of illuminance. (a), LIGHT (1); (b) LIGHT (2).

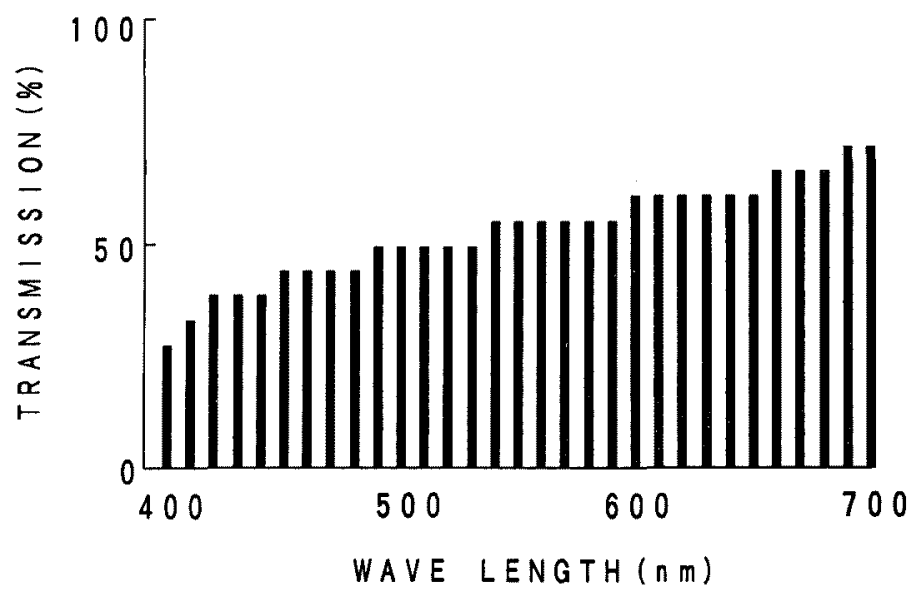

Fig. 2. Spectral transmission of opaque sheet.

梁さ $30 \mathrm{~cm}$ 东で入れた直径 $445 \mathrm{~mm}$ のパンライト水槛 に2つもしくは3つの照度域を次の方法で作った (Fig. 1)。水瞥壁の半分を黑色ビニールシートで覆い, 残りの 半分を乳白色ビニールシートで珡った。乳白色ビニール シート中央部の水槤内に黑色の遮光壁を取り付け，その 左右のビニールシートの枚数变变た（1枚，10枚）。乳 白色ビニールシートの分光透過率は Fig. 2 の様であり， $400 \sim 700 \mathrm{~nm}$ の可視光の籁囲では 27.5 71.5\% であっ た。上画忙半分（側面を黑色ビニールシートで翼った半
円) のみ，黒色の幕で囲った。照明は白色蛍光灯 (15W) により上方 (LIGHT (1)) と側方 (LIGHT (2) から行。 た。上方からの場合, Fig. 1-a のような, 照度がほぼ様 な2つの照度域 $(1,25001 \mathrm{x})$, 側方からの場合, Fig. 1-b のよらな3つの照度域 $(10,180,1000 \mathrm{~lx})$ ができた。质 魚を 50 尾, 飼育水ごとビーカーで寒験水槽に静かに入 れ，約 30 分後夷験を開始L，LIGHT (1) 执よび LIGHT (2)の場合の各照度域への蝟集分布を調べた。実験はをれ ぞれについて約 20 回繰り返し、渎は実験毎に新しい 
ものと交換した。

稚魚の走光行動 長方形水槽 (L $50 \mathrm{~cm}, \mathrm{~B} 30 \mathrm{~cm}, \mathrm{H}$ $35 \mathrm{~cm})$ の 1 面 $(50 \times 30 \mathrm{~cm})$ を観察用空とし，他の 3 面

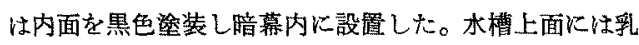
白色アクリル板を置き，その上方に $15 \mathrm{~W}$ 白色蛍光灯を 4 基据充た。水槽内に坂田沖の海水（可視光全域の照度 の消散保数 $2.8 \mathrm{~m}^{-1}$, 愁濁物量 $\left.0.86 \mathrm{mg} / \mathrm{l}\right)$ を深さ $30 \mathrm{~cm}$ まで入れた。水槽内の海中照度はフクリル板の上に重好 た乳白色ビニールシートの枚数を变えて 6 段階で变化さ やた（上層（水深 $5 \mathrm{~cm}$ )；5700，2800，1400，750, 440, 90 $\mid \mathrm{x})_{0}$ この場合，水槽内の中層 $(15 \mathrm{~cm}$ 深）怙上び下層 (25 cm 深) ではをれぞれ 4000，2000，1000，520，330， $65 \mathrm{Ix}$ 补よび 3500, 1350,870,400,270, $50 \mathrm{~lx}$ になった。 稚魚を大さ別炕 $10 \sim 14 \mathrm{~mm}$ 秥よび $18 \sim 22 \mathrm{~mm}$ の 2つのダループに分けた。それでれの大きさにおける日

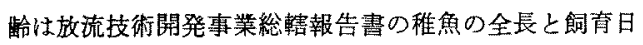
龄の関保式に上り求めると，約 25 日扣よび 45 日に該 当する。稚魚を大きさグループ別に 5 尾ずつ実鈳水槽内 に入れ，各照度域への蝟集状態と遊泳速度をどデオで調 べた。この行動観察は 1 回について 120 分間連続して行

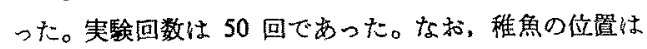
够端の位置とした。

稚魚の明暗境界域に対する行動反応 実験水槽は上面 を乳白色アリリル板で覆い，その半分のみ炕乳白色ビ二 ールシートを数枚重效て置いた。水槽上方に 15 W 白色 蛍光灯を 4 基設四し，上方から照明することにより明暗 の境界域をつくった。明域の水中照度 (承深 $5 \mathrm{~cm}$ ) は 1350 抬よび $30001 \mathrm{x}$ とし，この 2 つ場合の腤域の照度 (水深 $5 \mathrm{~cm}$ ) 沬 510, 270,100,50,30, $20 \mathrm{~lx}$, 抢よび 1100 . $590,220,100,65,501 \mathrm{x}$ とした。このときの明暗境界域

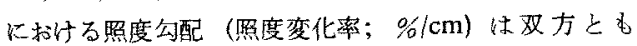
$0.18,0.23,0.40,0.63,1.00$ および $1.43 \% / \mathrm{cm}$ であった。 大きさグループ则に5尾ずつ明域に入れ，暗域への進入
率（全個体数に対する暗域へ進入した個体数の割合;\%) を調べた。実験は30回繰り返して行った。

\section{結果志よび考察}

仔魚の行動鹳察 䁔化後 1 日目 (全長 $2.1 \mathrm{~mm}$ ) の仔 魚は水面付近浮遊し，時折体を徽動させるのが観察さ $れ た 。 2$ 日目 (全長 $2.4 \mathrm{~mm}$ ) 快早朝最を明るい空倒の水

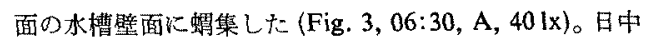
恃水面から水深 $10 \mathrm{~cm}$ 付近になんへんなく分散した(11: 30, A D, 90 115 lx)。夜間は照明側の水面に蛙集した

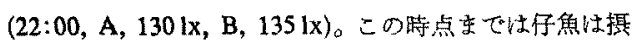
慨を行わなかった。

1. 仔魚の走光行動 睬化後 2 日目の仔魚について明 るさを変えたときの蚂集行動を調べた。その結果，照度 域が 1 と $2500 \mathrm{~lx}$ で俚 $2500 \mathrm{~lx}$ の方に蝟集した。照度域 かi 10,180,1000 lx の場合には $1000 \mathrm{~lx}$ 犆监した。す なかち，2 日目の仔魚は 1 2500 1xの範围では昭度がよ り高い所火蝟集した。このことからこの時点ですでに走 光性が㩆著にあると判断された。この時点に扔いて仔魚 の眼の墨化が肉眼で䘽察された。

䔡の光受容器は眼であるが, 兩眼間の頭頂, 頭骨下に ある上生体でる光を感知することが Omura and Oguri に上って明らかにされた。 Omura and Oguri 仕アニ Plecoglossus altivelis とヒラメ Paralichthys olivaceus of 魚の眼と上生体の分化を調べ，上生体の出現は眼より早 く，眼が発生する以前化批りるヒラメの昼夜間での鉛直

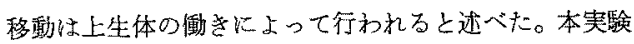
の場合，仔魚の眼はすで黒化していたことから，仔魚 㤬光を眼で感知していたるの上考光られる。

2. 稚魚の走光行動 Fig. 4 は種々の照度域への出現 率（全個体数に対する各照度域に出現した個体数の割 合；\%）の経時的变化である。出現率は全長 $10 \sim 14 \mathrm{~mm}$ 怙よび 18 22 mm の平均值で表しだ。種々の照度城へ

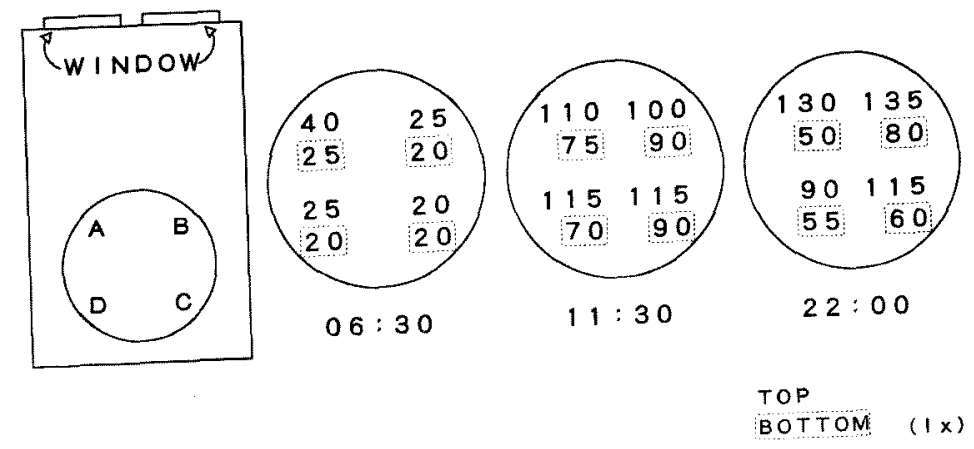

Fig. 3. Sketch of distribution of illuminance in feeding tank. A D, Locations where illuminance was measured. 


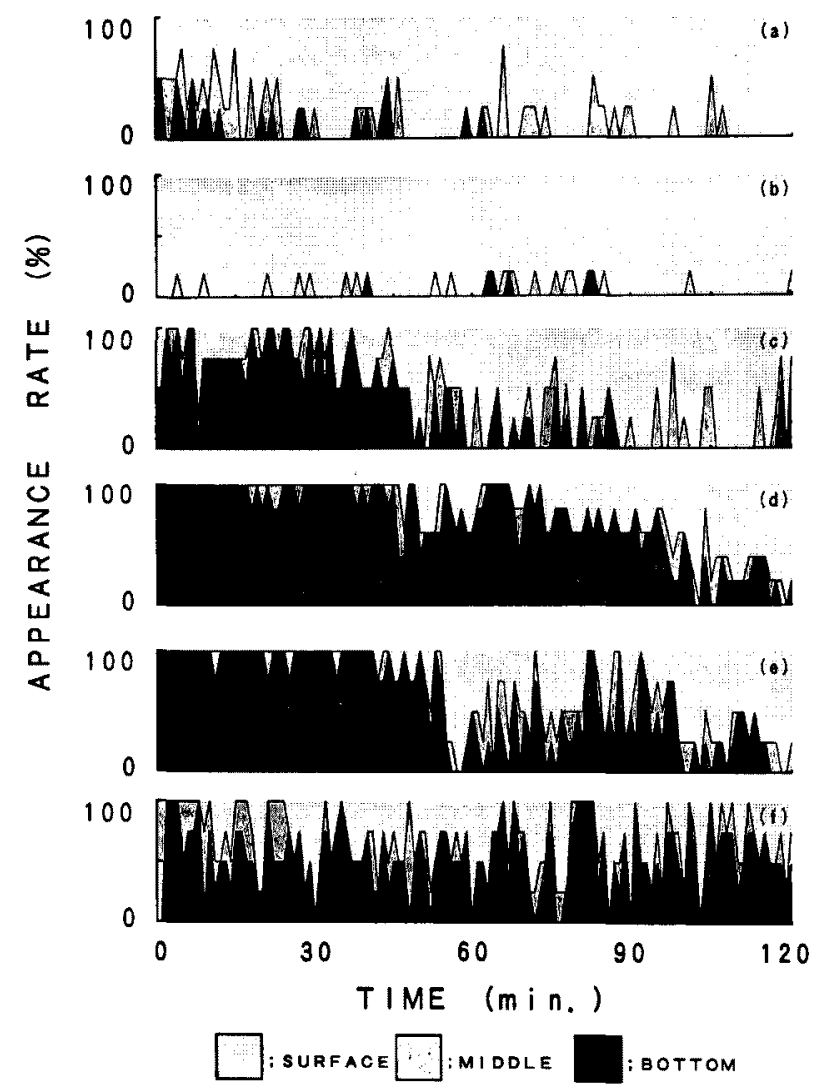

Fig. 4. Variation of appearance rates as a function of illuminance in water.

(a) Surface layer, 901x; Middle layer, $65 \mathrm{~lx}$; Bottom layer, $50 \mathrm{~lx}$.

(b) Surface layer, 440 lx; Middle layer, 330 lx; Bottom layer, 270 lx.

(c) Surface layer, 7501x; Middle layer, 520 lx; Bottom layer, 400 lx.

(d) Surface layer, $1400 \mathrm{~lx}$; Middle layer, $1000 \mathrm{~lx}$; Bottom layer, $870 \mathrm{~lx}$.

(e) Surface layer, $2800 \mathrm{~lx}$; Middle layer, $2000 \mathrm{~lx}$; Bottom layer, $1350 \mathrm{~lx}$.

(f) Surface layer, $5700 \mathrm{~lx}$; Middle layer, $4000 \mathrm{~lx}$; Bottom layer, $3500 \mathrm{~lx}$.

の出現率には体長別な違いがはとんど存在しなかった。

上膡への蝟集が最も湿著なのは $440 \mathrm{~lx}$ の埸会であり (蝟集率; 各照度域に程集した延へ個体数 $/ 120 \times$ 全個体数 95\%以上), 次いで $90 \mathrm{~lx}$ (蝴集率 85\%),750 Ix (䗀集率 56\%)であった。明るさが增すにしたがって下層への蜔 集が多くなり，2800 lx では鉛直に急浮上・急降下が見 られた。さらに57001x では激しく泳ざ回る鐠乱状態が 倠察された。以上上り，推魚が最も好さ照度は750 $1400 \mathrm{Ix}$ の籍䀳と又なされる。

遊泳速度を稚魚の単位時間市たりの移動仇跡を湘定し 求めた（稚魚が移㗢した距離/移勤時間; $\mathrm{cm} / \mathrm{s}) 。 440$ と $57001 \mathrm{x}$ の場合を比較すると、前者では平均 $0.4 \mathrm{~cm} / \mathrm{s}$, 標

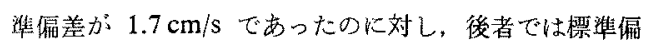
差前 $2.8 \mathrm{~cm} / \mathrm{s}$ と大きく、可均遊涾速度は $1.2 \mathrm{~cm} / \mathrm{s}$ であ
った。

3. 稚魚の明暗境界域に対する反応行動 照度勾配を 变えたときの稚奥の明域から暗域への進入率の变化を Fig. 5 に示した。照度勾配の增加に伴って進入率は減少 し、两者の関係は次式のよらに表された（相関係数 -0.89 )。

$$
O R=-15.9 \ln G+17.9
$$

ここで OR は暗域への進入率 $(\%), G$ は照度勾配 $(\%)$ $\mathrm{cm})$ である。以上より, 椎魚の明域から暗域への進入は 照度勾配によって制限され，照度勾配が $3 \% / \mathrm{cm}$ 以上で は進入できなくなることが確認された。

このことは天然海域に执ける藻付きたる影留を与える ことであり，千田"の調查で $100 \mathrm{~kg}$ 以上の大きな营では 幼雅魚が注とんど付いていなかったことの褧付けとして 


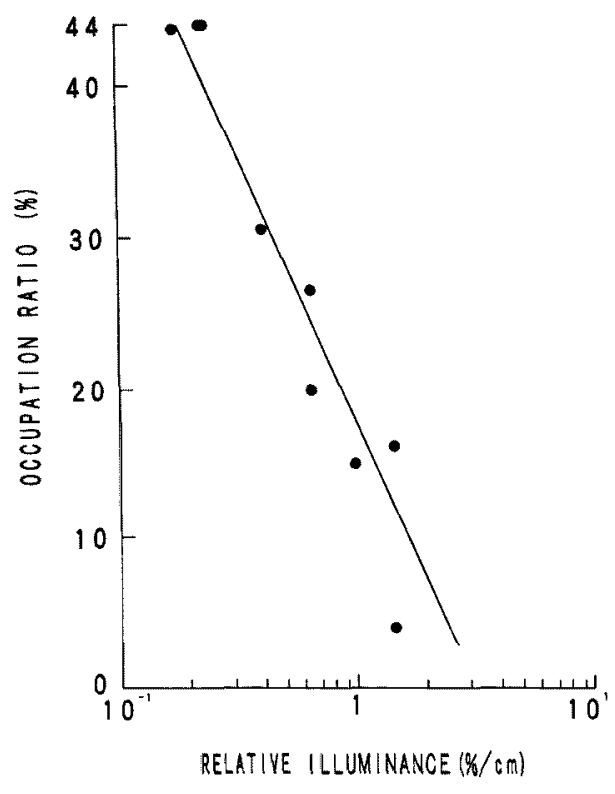

Fig. 5. Relationship between the occupation ratio and horizontal gradient of illuminance. The symbol - represents the mean values.

もみなすことができる。

このよらにイシダイ\}稚魚が成長にともない光環境を 選択することが判明した。沿岸のイシダイ資源の安定化
が棓られる現在，放流種苗数の增大が必須となっている しかしながら現状では，種苗生苇過程の中で光条件を配 勴した育成が十分に行われているとは言い難く、今後, 特に健苗性が高く，放流環境に適応能力を持つ種苗を放 流するためには，水温、飰の㻴境々ともに光環境上生物 特性の関係を十分に把握する必要があると考える。

\section{謝辞}

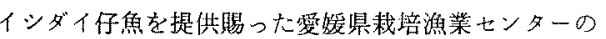

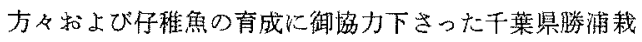
培㴔業センターの多の御好意に心から感謝の慧を表す \%o

稚魚の採集や実験等を御援助頂いた千葉综館山㴔協の 伊東久助氏, 坂田実験实習場の小池庵之主任拉よび技官

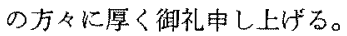

\section{文献}

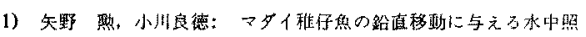

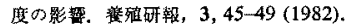

2) Y. Omura and M. Ogura: Photoreceptor development in the pineal organ and the eys of Plecoglossus altivelis and Paralichthys olivaceus (Teleostei), Cell Tissue Res., 266, 315-323 (1991).

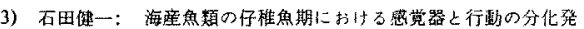
達に関寸万研究，博上学位諭文，東顶大学，來京，1984，pp. 1177.

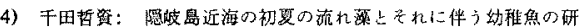
究. 生珰生態, 10,68-78 (1961). 